\title{
肘を支点として起立動作を簡便・安全にする自立支援システム
}

\section{Standing-up Motion Support System by Using Elbow Support Face to Adapt to Human Physical and Motion Characteristics}

初雁卓郎・パラマウントベッド

Takuro HATSUKARI, Paramount Bed Co., Ltd.
平田泰久・東北大学

Yasuhisa HIRATA, Tohoku Univ.
三宅徳久・パラマウントベッド

Norihisa MIYAKE, Paramount Bed Co., Ltd.

\author{
樋口淳一・東北大学
}

Jun'ichi HIGUCHI, Tohoku Univ.

Key Words: Medical and Welfare Assistance, Human Engineering, Human Interface

\author{
小菅一弘・東北大学
}

Kazuhiro KOSUGE, Tohoku Univ.

\section{論文要旨}

In this article, we propose a standing-up motion support system with elbow support face for elderly people and physically-handicapped persons, which enables the comfortable and stable human posture change based on physical and motion characteristic. Effectiveness of the standing-up motion support system is evaluated by using Organoleptic Evaluation, EMG and PHM. We demonstrate the effectiveness of the system by using these evaluating measure.

\section{1. 緒言}

日本では，高齢社会の到来に伴って日常生活に支障 のある高齢者が増加し続けており, 平成 16 年の時点で 400 万人に達している(1)。こうした人たちを支援する ために様々な介助技術が提案されているが, 代表的な 概念としてボディメカニクス ${ }^{(2)}$ とキネステティクス ${ }^{(3)}$ がある. ボディメカニクスとは, 被介助者を力学的に 身体負担の少ない動作で介助動作を行う概念である. 具体例として，仰臥位の人を側臥位にする体位変換を 挙げる. 膝を屈曲させて回転軸に対して遠い位置で力 を作用させる. 小さな力で大きなモーメントを出すこ とが可能となり，被介助者の腰の旋回動作を容易に実 現できる，一方キネステティクスとは，被介助者の自 立動作を支援することに注力して介助動作を行う概念 である．具体例として，ボディメカニクスと同様に， 仰臥位の人を側臥位にする体位変換を挙壮る．片膝だ けを屈曲させて本人に足を踏ん張ってもらうとともに, 屈曲させた蟐から大腿部を足方向に伸ばす．腰部の回 転を誘導し，直接的な腰の回転ではなく下肢のねじれ によって体位変換を実現している。 これらの介助動作 に共通しているのは，動作を分割すること，単一動作 で大きな負担を支援することの 2 点と考えられる。 こ こで単一動作とは, 体の 1 箇所に支点を作り，その点 を中心に体に作用を与える動作と定義する. ボディメ カニクスで言えば体幹軸を支点とした立膝先端の旋回 動作，キネステティクスで言えば踵を支点とした股関 節の伸展動作であり，ともに体位変換で最も大きな負 担を要する腰部の旋回動作を効率的に実現している. 本研究では, 看護・介護現場で実施されているこうし た介助技術を工学的に分析し，被介助者が自立動作可
能となる器具を提案することを目的としている．本稿 では，起立時の転倒事故が多いことを勘案して，目的 とする動作に起立動作を取り上げる.

まず, 健常者の起立動作を考える.山本らによれば(4) 起立動作は前傾相・前進相・伸展相に分けられるが, 伸展相では膝の伸展とともに腰の伸展を行うなど, こ の動作の実現には連続した複合動作が必要とされる.

次に，手すりを用いた起立動作を考える．手すりに は単独での起立動作が困難な人にも動作を実現できる 器具として広く使われているが, 主に 2 つの機能があ ると考えられる。ひとつめは，手に支点を作ることで 支持基底面を広げて安定性を向上させる機能である. ふたつめは，手に上体荷重を分散させることで下肢負 担を軽減する機能である．ただし，手すりと体幹との 間で上肢がて長であるために単一動作ではなく複合動 作が必要であり，平衡感覚が低下している人の中には 手すりを使っても安定性の確保方難しい人もいる。” た, リウマチや変形性関節症を持つ人の中には，手先 の巧緻性低下によっでグリップを握ることが難しくな る人や，関節に大きな負荷を与えると痛みを生じて手 すりを支点としづらくなる人もいる.

そこで本研究では, 肘を支点とする起立動作支援シ ステムを提案する. 肘を支点にすると端座位からの膝 の伸展を単一動作で安定して実現し, 前傾姿勢と慰部 離床を誘導して結果的に重心の前方移動および上方移 動を可能とする．手首を支点にすると上肢がて長自由 度を持つのに対して, 肘を支点にすると上肢が一意に 決まるため, 体幹が拘束され安定性が向上する.また, 肘を支点とすることで, 手先の巧緻性に依存せずに上 体の支持点を設けられる。

ただし，咒長自由度をなくすことは，使い方を限定 
することにつながる，肘を支点とする場合には，適正 な位置に支点を設置しないと起立動作が困難にもなり 得る. 従来でも, 时を支点として起立することは, テ ーブルや床固定式の専用パッドなどで実施される事例 もある．しかし，設置位置の妥当性は介助者の経験に よるところが多く, 数值的根拠は明確にされていない. そこで, 使用者の体形を考慮し, 安定性の向上と起立 動作の簡便性を両立させるシステムを提案する.

本稿ではまず，人を簡易モデル化して支点とする肘 の適正な位置を導出する. 次に, 本提案を実現するシ ステムを構築し, 通常の起立動作および手すりを用い た起立動作と比較する。評価方法としては, 安定性の 評価を官能評価と PHM で，身体負担の評価を官能評 価と筋電位計測にて実施し，その有效性を示す。

\section{2. 时を支点とする起立動作支援システム}

$2 \cdot 1$ 简易人体モデル人動作を定量的に表現す るために, 人体のモデル化を検討する.ここで, 看護 師や理学療法士を中心として看護・介護現場で取り入 れられているキネステティクスでは，人体をマスとつ

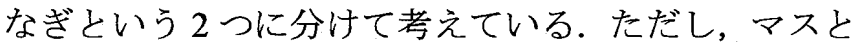
は重量を持つ体の部位であり，つなぎとはマスとマス をつなぐ関節部位と定義されている。キネステティク スによれば，マスは頭, 腕 (左右), 胴, 腰, 足 (左 右）の7部位で構成されており, 本研究でもこれを模 擬したモデルを考える。ただし，腕には肘，足には膝 という大きな関節があり自立動作にはこの関節の活 用が不可欠であることから，腕は前腕と上腕に，足は 下腿と大腿に分けて 11 のマスで構成されているもの とし，人を矢状平面上の 2 次元リンクモデルで考える

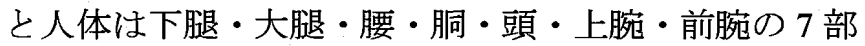
位に簡易化できる。これを, Denavit - Hartenberg の記 法を用いて人体を 7 リンクに近似した平面モデルを Fig.1 に示す. 起立動作時は足底部が接地したままであ るため外踝を下腿部と床との接触点と見なし, その点 を絶対座標系 $O_{0}-x_{0} y_{0}$ の原点とする. 外踝を関節 1 とし て, Fig.1に示すように, 順に各関節に番号をつけ.リ ンク座標系を定義する.ただし, 各リンク座標系 $O_{i}-x_{i} y_{i}$ でからみたリンク $i$ の重心位置べクトルを $\mathrm{s}_{\mathrm{i}}$, リンク $i$ - 1 の原点の位置ベクトルを $\mathbf{~}_{\mathbf{i}}$ とし, リンク $i$ 質量を $m_{i}$ とする.

$2 \cdot 2$ 时を支点とする起立怔作 前腕を水平にして 肘関節を支点とする場合，尺骨が前腕の広い面積を持 って接触できるため接触面が安定するとともに，上腕 骨が尺骨と大きな関節で支持されるため，体に対して 負担が少ない動作になる。 そこで, 肘を支点とする起 立動作が高齢者や障害者に対して有効と考える．ただ し, 肘関節の支持位置によっては, 起立動作を抑制す る方向に力が作用する。 そこで, 起立動作を促進しな がら上体を支えられる肘支持位置を検討する.

起立動作においては，体幹を前傾させながら重心を 押し上げる動作が必要である．肘を支点とした起立動 作を考える際に，肘から上腕への軸力が反力として加 わると仮定する. 上腕と前腕のなす角が $90^{\circ}$ 以上の場 合は, 反力が肩関節を後方に押し戻す方向となり, 体 幹が後傾する方向に作用する (Fig.2(a)参照)．逆に，

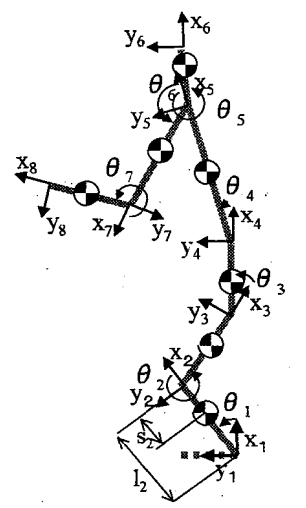

joint 1 : ankle

joint $2:$ knee

joint 3 : greater trochanter

joint 4 : iliac crest

joint 5 : acrominon

joint 6 : temple

joint 7 : elbow

joint 8 : wrist

Fig. 1 Planer link model of a human

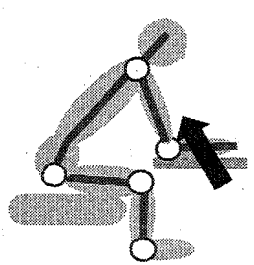

(a) Wide Angle

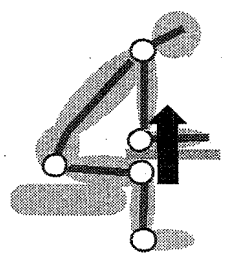

(b) Right Angle

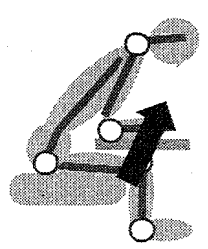

(c) Narrow Angle $90^{\circ}$ 末満の場合は肩関節を前力に押し出す方向となり, 起立動作を促進する方向に作用する (Fig.2(b),(c)参照). ただし，上腕と前腕のなす角を小さくし過ぎると軸力 の方向が水平方向に近づくため, 反重力方向に力を作 用させることが難しくなる. そこで，2-1の簡易人体モ デルで水平にした前腕に対する上腕のなす角が $90^{\circ}$ となるとともに, 膝と肘の水平方向位置が同じとなる よう肘支持位置を考える (Fig.2(b)参照).

$2 \cdot 3$ 人の特性にあわせるシステム設定 Fig.2(b) と なるような肘支持部の地上高 $\mathrm{L}_{2}$ は下式で表される.

$$
L_{2}=l_{1}+l_{2} \cos \theta_{1}+\sqrt{\left(l_{4}+l_{5}\right)^{2}-l_{3}^{2}}-l_{7}
$$

ただし, $1_{1}$ は外踝地上高, $1_{2}$ は下腿長, $1_{3}$ は大腿長, $1_{4}+l_{5}$ は大転子・肩峰長, 17 は肩峰・肘回転中心長, $\theta_{1}$ は 鈆直軸と下腿とのなす角とする.

\section{3. 起立勳作支援システムの概要}

試作した起立動作支援システムを Fig.3に示す.本シ ステムは昇降機能付ベッドの就葠面に設置するものと する. すると，(1)式で表される肘支持部の地上高のう ち外踝地上高や下腿長はベッドで調節可能なため, 本 システムが人の特性にあわせるための設置高さ可変量 L

$$
L_{2 b}=\sqrt{\left(l_{4}+l_{5}\right)^{2}-l_{3}^{2}}-l_{7}
$$

となる. 60 歳以上の高龄者で $5 \%$ タイルから $95 \%$ タイ ルの人まで勘案すると $\mathrm{L}_{2 b}$ は $43.6 \mathrm{~mm}$ であることから， 上下方向に $50 \mathrm{~mm}$ の可動範囲を持つ肘支持部とする.

(2)式に個人寸法を適用させて起立動作した様子を

Fig.4に示す. スムーズな起立動作になることがわかる. また起立後の動作を勘案して本アイテムをベッド就 
寝面設置としたことにより, 足元に動作空間を確保し, 転倒要因や車イスが干渉して近づけられないといった 懸念事項が解消されることも特長とする.

\section{4. 起立動作支援システムの有効性検証}

4-1 評価方法起立動作に支障のある人が自立動作 を実現するためには，身体負担の低減と安定性の向上 が求められる。そこで，自助具なしの起立動作，市販 の手すりを用いた片手支持を用いた起立動作と 3 章で 提案したシステムの比較評価を実施して (Fig.5 参照), 提案の有効性を示す.

(a) 官能評価体感的な評価として, 官能評価を実 施する. 官能評価は動作負担と安定性について相対比 較による 5 段階で評価を行う。ただし，被験者が健常 者であることから自助具なしの起立に負担や不安定さ を感じることは少ないため，片手支持手すりを基準と した相対比較とし, 手すりより良ければ 5 点, 手すり と同等であれば 3 点, 手すりより悪ければ 1 点とする. また，負担の大きい動作として，臀部離床時と伸展動 作時が考えられるため，2 つの動作を分けて評価を実 施する。

(b) 筋電位計測動作負担量の評価指標として一般 的には, 関節モーメントや筋電位を用いることが多い. 本システムは，左右いずれか片側の肘を支点とするこ とから動作が左右対称とならないため, 関節モーメン トによる評価は困難と判断し，3 次元動作でも計測可 能な筋電位を身体負担の評価指標として用いることと する。

(c) PHM 本研究では, 安定性の指標としてこれまで, 下式で表される PHM (Posture Holding Moment) を採用 してきた (3)

$$
\tau_{P H M}=\sum_{j}\left(\mathbf{r}_{\mathbf{g}}-\mathbf{r}_{\mathbf{j}}\right) \times \mathbf{F}_{\mathbf{j}}
$$

ただし，慣性座標系における人体モデルの重心位置べ クトルを $\mathbf{r}_{\mathbf{g}}$, 慣性座標系において人体モデルが外力を 受ける位置べクトルを $\mathbf{r}_{\mathbf{j}}$, 外力を $\mathbf{F}_{\mathbf{j}}$ で表す.

(3)式は 3 次元空間でも 2 次元平面と同様に定義され るため, これを安定性の指標として用いることとする.

\section{4:2 实験}

（a）官能評価被験者は若年健常者で男性 3 名，女 性 3 名とする. 各評価項目について試行は 3 回とする. 肘を支点とした起立動作支援システムは(2)式に基づ いて個人に合わせた設置位置として評価を行う。

\section{(b) 筋電位計測 筋電位計測は, 大腿直筋, 腹直筋,} 僧帽筋，上腕二頭筋，上腕三頭筋，腕橈骨筋の 6 点を \% MVC 值で評価する.ここで，腓腹筋および金柱起立筋 についても予備実験で計測を実施したが，有意差が見 られなかったため試験項目から除外してある。計測器 はBIOPAC MP150 システムを用い，電極にはディスポ 一ザブル電極EL503 を使用し, 主力ゲインは5,000 倍,

ローパスフィルタは $10 \mathrm{~Hz}$ ，ハイパスフィルタは $500 \mathrm{~Hz}$ とする。被験者は身長 $170 \mathrm{~cm}$, 体重 $65 \mathrm{~kg}$, 年齢 31 歳 の男性健常者として, 各試験項目について試行は 3 回 とする。(a)と同様に，被験者が健常であることから，

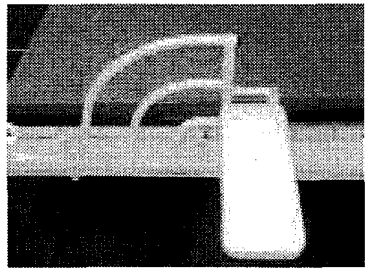

Fig.3 Standing-up Motion Support Device
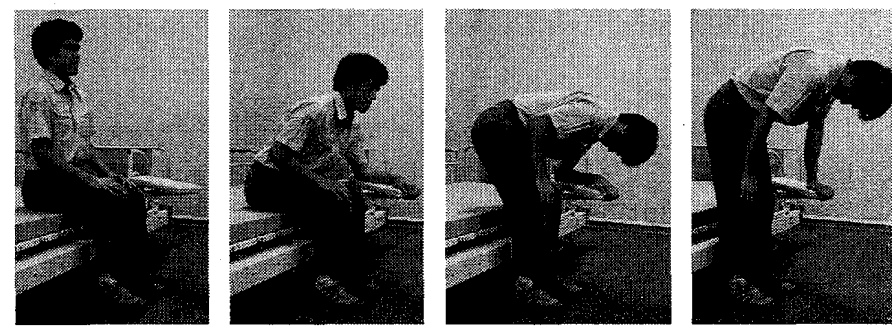

Fig.4 Standing-up Motion with Elbow Support Face
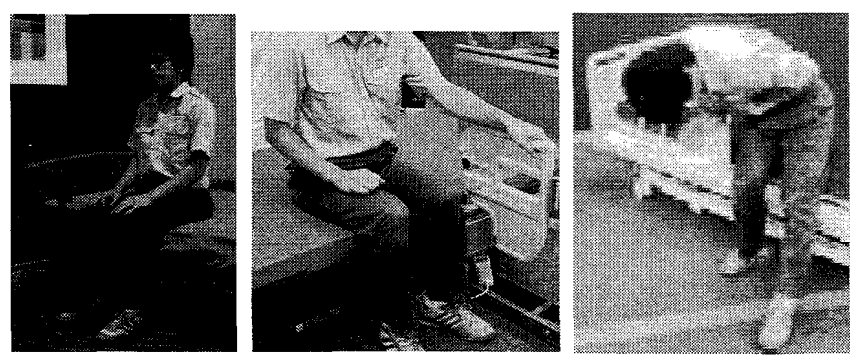

(a)Without Device (b)Hand Grip (c)Elbow Support Face Fig. 5 Standing-up Motion Support Device

本実験での比較対象は片手手すりを用いた起立動作と する。

(c) PHM PHM は Fig.1 の各回転軸にマーカを設置 し， 3 次元動作解析装置（Qualisys Proreflex）により各 関節の軌跡を得る。また，支持点となる足部，臂部， 手もしくは肘部に力センサを設置して作用力を検出す る（足部，眤部：KISTLER 9286AA，手もしくは肘部： Nitta 100M40A)。被験者は(b)と同じとして，各試験項 目について試行は 3 回とする.

\section{3 結果}

（a）官能評価官能評価を実施した結果について， 平均点と標準偏差を評価項目別に Fig. 6 に示す. 片手支 持手すりを 3 点で基準としていることから，臂部離床 時では動作負担および安定性ともに有意差があり，肘 を支点とした起立動作支援システムは有効であること がわかる，また，伸展動作時においても，統計的有意 差はないが平均では上回っており，本システムの有効 性が示された，以上より，起立の一連の動作において 本システムが手すりよりも有効であることを官能評価 により示した.

(b) 筋電位計測 筋電位計測による身体負担の評 価結果について，測定例として EMG の時系列変化を Fig.7 に示す. Fig.7(a)を見るとすべての筋群におうて大 きな変動がなく, 動作負担の少ない理想的な動きをし きな変動がなく，動作負担の少ない理想的な動きをし ていることがわかる。つまり，平衡感覚があれば手す りを使わない方が動作負担は小さいと考えられる。 


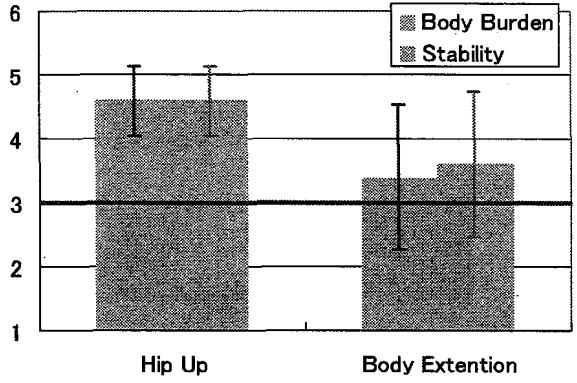

Fig.6 Organoleptic Evaluation of Standing-up Motion

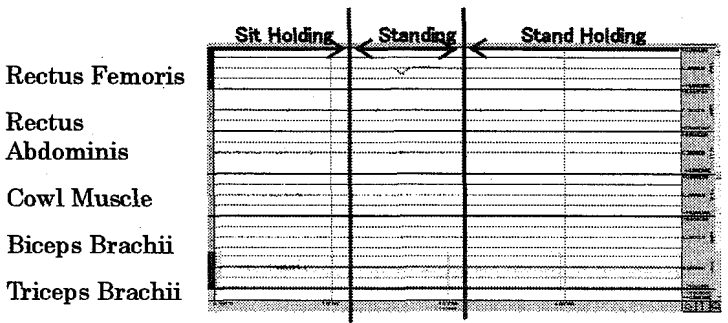

(a) Without Device

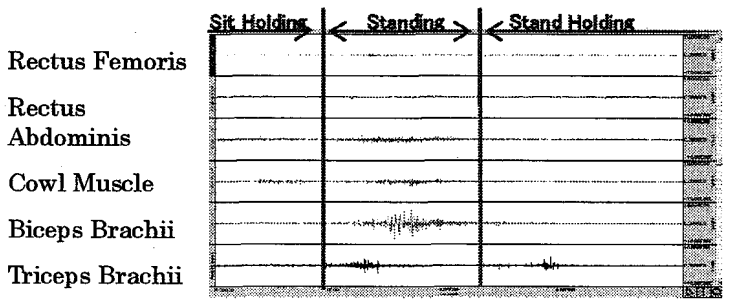

(b) Hand Grip

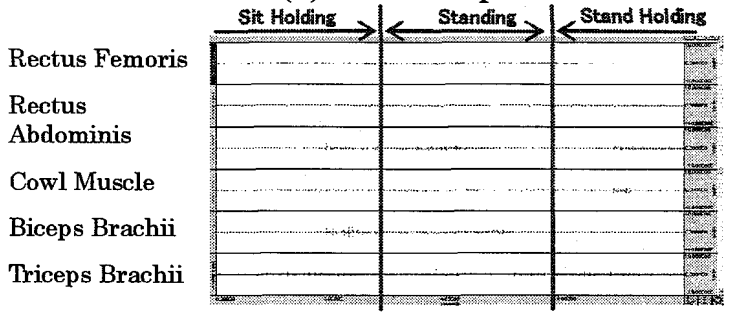

(c) Elbow Support Face

Fig. 7 Measuring Example of EMG of Standing-up Motion

Fig.7(b)(c)より，手すりなしと比べて上肢の筋負担はと もに増大しているが，时を支点とした起立では片手支 持手すりによる起立と比べて腹直筋にほとんど変位が なく, 前傾姿勢を保持するための筋力が大幅に低減で きることがわかる。ここで，最大\%EMG 值の平均値お よび標準偏差を Fig.8に示す.手すりを用いた場合は腹 直筋および上腕三頭筋に顕著な増大が確認されるのに 対し，肘を支点とした起立では自助具なしと比べても 上肢負担にほとんど差異がないことが確認される。よ って, 本システムが手すりよりも小さい身体負担で起 立できることが, 筋電位計測により定量的に示された. (c) PHM PHM 計測による安定性の評価結果につい て, 起立手法別の計測例を Fig.9 に示す. 自助具なしお よび片手支持手すりでの起立動作では慰部離床時に PHM が増大し，不安定となることがわかる。これに対 し, 肘を支点とした起立では臂部離床時に逆に安定性 が向上することがわかる．起立手法別に最大 PHM の 平均值と標準偏差を Fig. 10 に示す．手すりを用いた起 立動作では自助具なしの起立動作と有意差が見られる

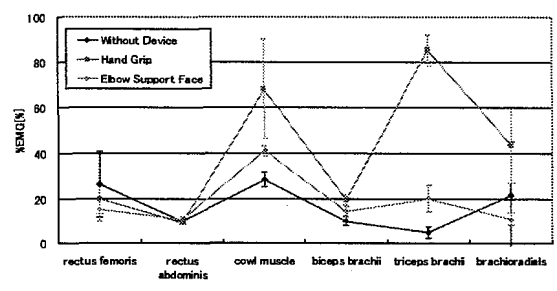

Fig. 8 EMG of Standing-up Motion

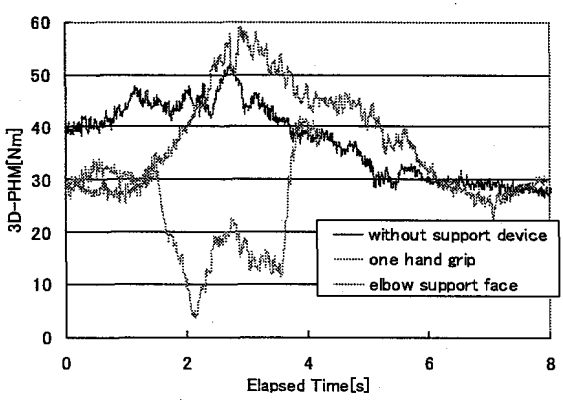

Fig.9 Measuring Example of PHM

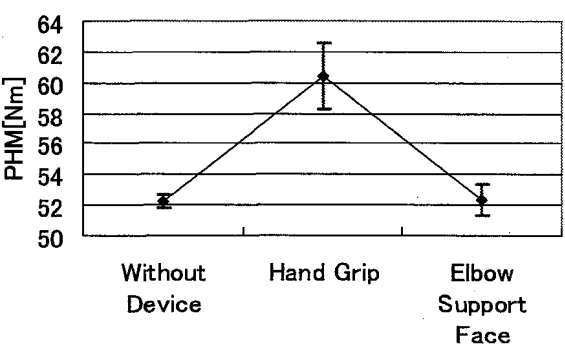

Fig.10 PHM

のに対し，肘を支点とした起立動作支援システムは手 すりを用いた起立には有意差のある安定性向上を確認 でき，自助具なしの起立動作と同等と考えられる。よ って，本システムが手すりよりも安定性が向上するこ とが PHM 計測により定量的に示された。

\section{5. 結言}

本研究では，要介助者が自立動作を可能とするため の手法として, 動作を分割して単一動作によって負担 の大きな動作を支援するシステムを検討している．本 稿では動作の例として起立動作を挙げ，肘を支点とし た膝伸展の単一動作により動作を安定かつ省力化でき る自立支援システムを提案した。人の身体寸法にあわ せて位置を調整可能とすることを特長とし, 起立・着座 前後の動作も勘案したレイアウトとなる起立動作支援 システムを試作した。これを既存の起立動作と比較評 価し，定性的な評価として官能評価を，定量的な評価 として動作負担を筋電位計測で，安定性を PHM 計測 により行い，いずれの評価によっても提案したシステ ムが有効であることを確認した。

\section{参考文献}

（1）“平成 16 年国民生活基礎調查”，厚生労働省.

（2）山本, 加藤, 中村: “腰痛を防ぐ らくらく動作介助マニュア ル”, 医学書院, 2002.

（3）氏家，阿曾，井卜：“基礎看護技術 I 第 6 版”, 医学書 院, 2005

(4) 德永: “キネステティク概念を応用した体位変換の実際”, 裖 瘡会誌, 3(3), pp.259-267, 2001. 